\title{
Women Empowerment and Social Development in Afghanistan through Micro Finance
}

\section{Mahboob Ullah}

To Link this Article: http://dx.doi.org/10.6007/IJARBSS/v10-i12/8324

DOI:10.6007/IJARBSS/v10-i12/8324

Received: 12 October 2020, Revised: 14 November 2020, Accepted: 30 November 2020

Published Online: 10 December 2020

In-Text Citation: (Ullah, 2020)

To Cite this Article: Ullah, M. (2020). Women Empowerment and Social Development in Afghanistan through Micro Finance. International Journal of Academic Research in Business and Social Sciences, 10(12), 377389.

\section{Copyright: (c) 2020 The Author(s)}

Published by Human Resource Management Academic Research Society (www.hrmars.com) This article is published under the Creative Commons Attribution (CC BY 4.0) license. Anyone may reproduce, distribute, translate and create derivative works of this article (for both commercial and non-commercial purposes), subject to full attribution to the original publication and authors. The full terms of this license may be seen at: http://creativecommons.org/licences/by/4.0/legalcode

Full Terms \& Conditions of access and use can be found at http://hrmars.com/index.php/pages/detail/publication-ethics 


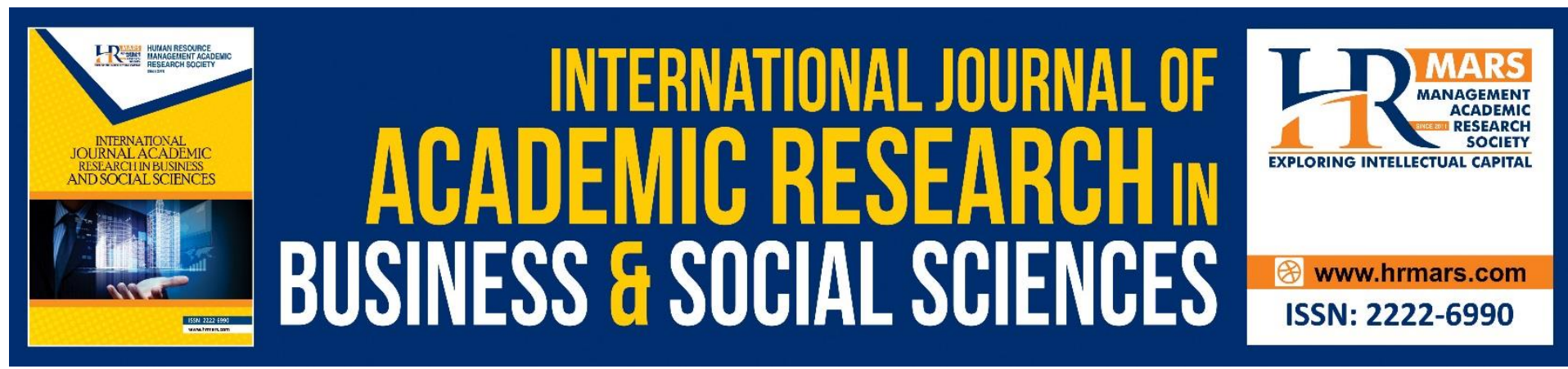

\title{
Women Empowerment and Social Development in Afghanistan through Micro Finance
}

\author{
Dr. Mahboob Ullah \\ Associate Proofessor, Al-Taqwa University, Nangarhar Afghanistan
}

\begin{abstract}
Micro finance is used to support individual and small businesses across the globe. This research is conducted to investigate the impact of micro finance on women empowerment (participation rate, mobility, freedom of expression of thoughts, and decision making approach towards flexible life) and social development (social status and living standards) in Afghanistan. For accomplishment of research objective, data was collected from 110 respondents (home based and non-home based individual/businesswomen) in Jalalabad, Laghman, Kunar, Kama, Khogyani, and Kot, Afghanistan through structured open and closed ended questionnaire. The hypotheses were tested by deploying multiple linear regression model. Data was analyzed through SPSS version 22. Data reliability was checked through Cronbach's Alpha test. The outcomes indicated that micro financing have positive impact on women empowerment and social development. The outcomes documented that micro financing is a significant tool that maximize women empowerment in all dimensions. Furthermore, micro financing enhance social development of women. Micro finance is a significant element of financial institution that instill women confidence in decision making: both in domestic activities and in business \& social activities that further leads to economic contributions in support of families which is considered as a step towards prosperity. This research is useful for the government and policy makers of Afghanistan as it documents the importance of micro financing in empowering women and social development.
\end{abstract}

Keywords: Microfinance, Women Empowerment, Social Development, and Afghanistan.

\section{Introduction}

Afghanistan having topology of vast area covered with dry rocks. In Afghanistan, there are 34 provinces and 421 districts with a total population of 37,902,806 where there are $51.7 \%$ male and $48.3 \%$ are female. The employment to population ratio of female under age of 15-24 years in Afghanistan is about 16.08\% (Afghanistan Central Statistics Organization, 2019). Due to unsound domestic circumstances and less stable government, this land suffered a lot. There have been strict restrictions for women in most of the sphere, however with the passage of time awareness among women and role of activists succeeded to assess the women right. In this modern era, women are performing their duties in many sectors in Afghanistan. Many women are involved in home based and non-home based businesses. In order to support and instill the confidence of women, government, international donors and financial institutions have launched different financial supporting programs in Afghanistan, 
and micro finance is one of them. Micro finance got peaked with the expansion of existing banking sector in the remote areas as well as establishment of new banks across Afghanistan (Emily, 2017).

Afghanistan is ranked in the list of under developed economies, like other underdeveloped economies, Afghanistan also have the same challenges ahead such as lawlessness, social insecurity, lack of infrastructure, lack of efficient health facilities, and lack of proper education, unemployment, poverty and so on. According to Afghanistan Central Statistics Organization, (2019), around 54.5 \% population of Afghanistan lives below poverty line.

In this modern era, unemployment and poverty are the root causes of economic problem across the globe. These two macroeconomic indicators are interlinked because due to unemployment the poverty rate rises. The governments of underdeveloped as well as developed countries have been striving to provide employment opportunities to their citizens in order to alleviate poverty and improve living standard. For this purpose, policies have been developed and implemented in different periods, however some were found very fruitful and some were failed world-wide and in Afghanistan (Afghanistan Research Newsletter, 2019).

Poverty is a phenomenon of lack of basic needs while this term mostly associated with social and economic norms (Gurses, 2018). Due to high inflation and currency devaluation, many families pushed down to the poverty line or under threshold levels due to which poor families remain unable to meet their basic needs. Around 7 billion populations across the globe, 3.4 billion people live below threshold level of poverty by earning less than $\$ 2$ per day. In short, half of the populations across the globe live below poverty line (Hicks, 2019). Poverty is the root cause of low literacy rate, weak living standard, and poor health facilities that lead to vulnerable situation and give rise to the criminal activities. Weiss, Montgomery and Kurmanalieva (2013), classified poor as chronic poor (permanent poor) and transitory poor (temporarily fall into vulnerable conditions). Morris and Barnes (2005) described poverty is the lack of access towards choices for a satisfied social life. Morris and Barnes (2016) concluded that poverty is the lack of financial and social status.

In such vulnerable situation in Afghanistan, micro finance is a ray of light that enable people to earn and support families through small businesses at home and in the market. Many women have commenced own businesses by obtaining micro finance loans on low mark up from financial institutions in Afghanistan (Mansfield, 2018). Microfinance has become the most effective tool in poverty alleviation, women empowerment, and social development worldwide. In addition, micro finance gives rise to home based businesses that is operated by women.

Micro financing institutions and micro finance banks are the regulated bodies performing their role efficiently in poverty alleviation and women empowerment in Afghanistan. There are 12 functional banks in Afghanistan, consisting 3 central banks, 7 private banks, and 2 foreign banks (Afghanistan Central Statistics Organization, 2019). Micro finance support small businesses, local markets and home based business (mostly run by the women) through micro credit on low interest rate. This financial support is based on low interest, easy procedure, and on easily installments for short period of time.

Dr. Muhammad Younas, the inventor of microfinance, practiced micro-financing for the purpose of poverty alleviation and social development in Jobra village of Bangladesh. Hence, micro finance plays a pivotal role in helping vulnerable families by providing loans to alleviate poverty, empower women, and develop them socially (Okafor, 2016). 


\section{Problem Statement}

Mawa (2018) described the term poverty as the situation in which the influence of lower middle class is unable to meet their basic needs of life. There is male domination in third world countries such as Afghanistan where women counter parts are literally dependent on head of the family and remain dominated in terms of decisions regarding household affairs, education, investment and accesses towards financial intermediaries. Therefore, in under-developed countries women are considered as less empowered as compare to male.

Zaman (2015) defined empowerment as "a process which supplements individuals and groups competencies to act upon their choices by selecting from available choices, therefore women empowerment is more important than men empowerment". Women empowerment is a complex phenomenon as it is not only the empowerment of one woman rather this empowerment leads to entire family and whole nation. Mohindra, Katherine, and Haddad (2015) used 8 dimensions to address women empowerment including economic safety, participation in key household affairs, less family restrictions, small and large purchasing decisions, political and legal awareness, mobility, participation in politics and protest. Microfinance creates value to women empowerment and social development as it enable them to make decisions regarding families, improve bargaining power, access to information/education, credit, and rising living standards.

According to author knowledge, studies have been conducted on women empowerment through microfinance in developed and developing economies (Mawa, 2018; Mohammad, Khan, Mohammed, Rahaman, 2017; Niaz \& Iqbal, 2019) but lesser attention has been devoted to human and social development through micro-financing in a country like Afghanistan. Therefore, it is indispensible conduct a research to analyze the impact of micro credit on women empowerment and social development as micro finance is the key source of social and economic development in a country like Afghanistan. This research is carried to combine the role of micro financing in women empowerment, social development, and poverty alleviation as they are interlinked. This research documents the aspect to be focused including the influence of socio-economic and demographic factors on income generation ability by empowering women, information about microfinance and its impact on social development in Afghanistan. This research measures women empowerment with dimensions: participation rate, mobility, freedom of expression of thoughts, and decision making approach towards flexible life and social development with facets: social status and living standards in order to analyze the influence of micro credit in the districts of Jalalabad, Laghman, Kunar, Kama, Khogyani, and Kot, Afghanistan.

\section{Research Objectives}

1. The research aimed to analyze the role of micro finance in women empowerment and social development in Afghanistan.

2. To make deep insights to understand the impact of microfinance on poverty alleviation.

\section{Research Questions}

What is the impact of micro finance on women empowerment and social development in Afghanistan?

1. How micro financing lifts up social development and alleviate poverty by empowering women in Afghanistan? 


\section{Literature Review}

According to Ali, and Alam (2017), being empowered is the name of inner change that give rights to make preferences and decision in terms of capability to make individual's life easy. Bakhtiari (2016) reported that being empowered is the progression which give rise to the ability of humans to sort right decisions among given choices to act according to their desires. Gangadhar and Malyadri (2015) defined women empowerment "to develop self-confidence, self-esteem, courage to make choices, implement bargaining power, and the right to live in their own way. According to Morris and Barnes (2016), empowerment is the name of living according to one's own way. Empowering someone is an important phenomenon but still there is no any precise method of measuring as it has not been developed by any organization. However, Kim, Watts, Hargreaves, Ndhlovu, Phetla, and Morison (2017) addressed Gender Empowerment Measure (GEM) \& Gender Development Index (GDI), the methods used previously for measurement of empowerment. Gopalan, (2017) defined empowerment as "complex human psyche tested by certain realistic dimensions: decision-making, selfconfidence, and self-esteem that may directly affect human nature".

Gurses, (2018) tested women empowerment using eight dimensions such as economic $\&$ social security, participation in most family decisions $\&$ politics, access and large $\&$ small purchase decision, freedom from family restrictions, political, and social and legal awareness. Gopalan (2017) investigated the impact of micro financing on levels of income and financial assets in Bangladesh. The results showed a positive relationship between micro finance program and income \& financial assets. They elaborated that the micro finance programs give rise to assets building capacity of women as it increase the earning of women entrepreneurs up to $18 \%$.

According to Avolio, Yammanno, and Bass (2016), micro finance itself is not a way out to alleviate poverty income but it is a solution for the said problem. Micro financing programs not only support poor but it coordinates with other enterprises (joint venture and partnership) to create employment opportunities and fulfill the social and basic requirements of poor. According to Emily (2019), poverty is a gigantic issue that has been faced by developed, under developed and developing countries. Around three billion people lives below poverty line. Herani, Dhakan, (2017) concluded a research that there is discrimination among rich and poor nations. They documented further that advanced countries showed economic growth and highest GDP while on the other hand there is tangent situation in third world countries where there is massive starvation and famine, and children die because of lack of sufficient health facilities and food shortage.

Niaz and lqbal (2019) determined the relationship between women empowerment and micro finance schemes in Pakistan using OLS technique. The study focused on achievement of sustainable development goals such as poverty reduction. It was concluded that micro finance institutions were effective mechanism in terms of targeted SDGs and poverty reduction through empowering women. Bakhtiari (2016) investigated the influence of microfinance on empowering women in Andhra Pradesh using paired sample t test. The comparison was made through t-test in women's perceptions towards before and after attainment of micro finance credit. The estimates indicated that the micro financing is an important instrument which can enhance the women empowerment for entire dimensions (decision making in household affairs, legal and social awareness, mobility, economic security, and family decision making). 


\section{Research Hypotheses}

$\mathbf{H}_{1}$ : Micro finance positively and significantly affects women empowerment.

$\mathbf{H}_{\mathbf{2}}$ : Micro finance positively and significantly affects social development.

\section{Conceptual Framework}

The below given conceptual model is developed in line with the previous research work done on micro finance (independent variable) and its impact on women empowerment and social development (dependent variables). The conceptual framework is developed from the earlier research: impact of micro finance on women empowerment (Kim et. al., 2017; Mawa, 2018; Mohammad, Khan, Mohammed, Rahaman, 2017) and impact of micro finance on social development (Herani, Dhakan, 2017; Mohindra, Katherine, Haddad, 2015).

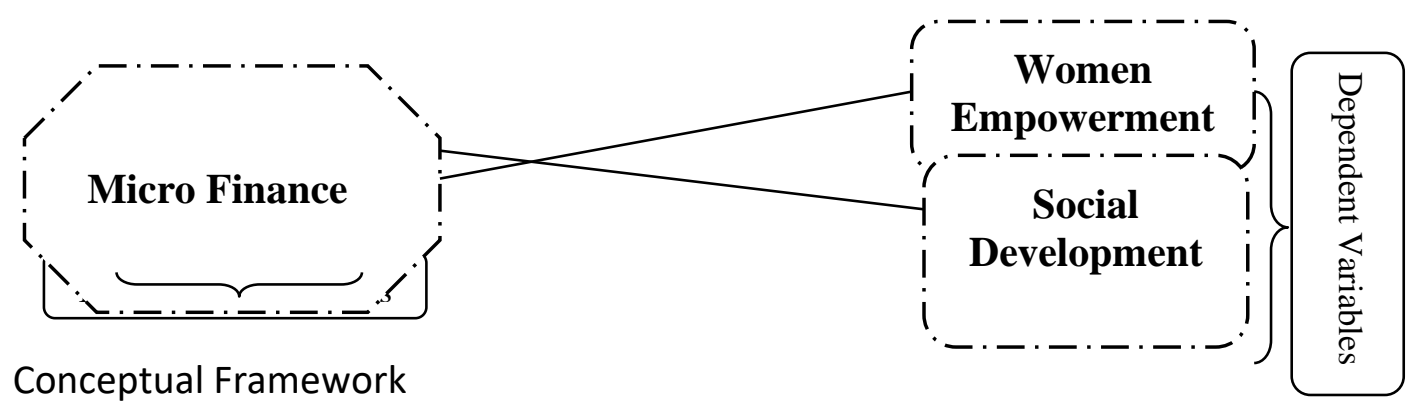

Figure 1 Conceptual Framework

\section{Research Methodology}

A self-administrated questionnaire based on women empowerment and social development in Afghanistan through micro finance was used in this research as the variables employed in this research similar to variables used by (Chapman, \& Chapman, 2017). The primary data was collected through questionnaire, administered by interviewer because some of the respondents were unable to understand the written questions. The questionnaire was also narrated from English to their native language (Pashto). The initial part of the questionnaire consisted of demographic questions, followed by women empowerment and social development (dependent variables) and micro credit (independent variable). Questionnaire comprised of questions related the demography of the respondents, social development, women empowerment, and poverty from selected districts: Jalalabad, Laghman, Kunar, Kama, Khogyani, and Kot, Afghanistan. There were 15 questions in questionnaire and 7 Likert rating scale was used to collect responses while respondents respond accordingly for open ended questions. Few changes were made in questionnaire after pilot study using 20 respondents.

The general characteristics of sample respondents discussed in this section by using the descriptive statistics. According to the below given Table 1, the age of the sample respondents were 25 to 68 years. $13 \%$ respondents were of the age of $\geq 29,22 \%$ were of 30 to 39 years, $22 \%$ of 40 to 49 years, age of $25 \%$ respondents was 50 to 59 years while $16 \%$ respondents were of $\leq 60$. The ratio of middle age respondents was comparatively high. Education levels classified as metric, secondary, graduate, masters and above uneducated. The education level of the respondents was 34.5\% (matriculate), $9 \%$ (intermediates), $9 \%$ (graduates), $6 \%$ (master), and 50\% (uneducated). Family size can also influence income/consumption level positively i.e. increasing number of family members may increase the consumption and lowers down the income and savings. The family composition of $45 \%$ was ( $\geq 5$ ) family members, $45 \%$ were (6-9), and $9 \%$ were (10-11) family members. Marital status was described as single, married, divorced, widows, where $44.5 \%$ respondents were 
married,23.6\% were unmarried, $18 \%$ were divorced and $13.6 \%$ widows. This research has measured two types of businesses: home based and non-home based. $54.5 \%$ female were involved in non-home based businesses while 45.4 were involved in home based businesses.

Table 1: Socio-Economic and Demographic Features of Respondents

\begin{tabular}{llll}
\hline \multicolumn{1}{c}{ Characteristics } & & No. of Respondents & Percentage \\
\hline \multirow{3}{*}{ Age(Years) } & $\geq 29$ & 15 & 13 \\
& $30-39$ & 25 & 22 \\
& $40-49$ & 24 & 22 \\
Education level & $50-59$ & 28 & 25 \\
& $\leq 60$ & 18 & 16 \\
& Metric & 38 & 34.5 \\
& Secondary & 10 & 9 \\
& Graduate & 10 & 9 \\
Family size & Masters and & 7 & 6.3 \\
& Above & 45 & 40.9 \\
& Uneducated & & \\
Marital Status & Less or equal to 5 & 50 & 45.4 \\
& 6-9 & 50 & 45.4 \\
Type of business & $10-11$ & 10 & 9 \\
& Married & 49 & 44.5 \\
& Single & 26 & 23.6 \\
& Divorced & 20 & 18 \\
& Widow & 15 & 13.6 \\
& Non Home based & 60 & 54.5 \\
& Home based & 50 & 45.4 \\
\hline
\end{tabular}

The given below Table 2 documents the income variation of different age groups. The earnings of first group were comparatively lesser than others as they might be new professionals. The income levels of $4^{\text {th }}$ age group highest because of wider experience. The last age group respondents due to older age and lower work potential might earn less same as life cycle.

Multiple empirical analysis carried out to investigate the impact of micro finance on women empowerment, social development, and poverty alleviation.

Table: 2 Economic Indicators

\begin{tabular}{|c|c|c|c|c|}
\hline \multicolumn{2}{|c|}{ Characteristics } & Percentage & \multirow{2}{*}{$\begin{array}{l}\text { Average } \\
\text { Income Per } \\
\text { Month } \\
21358\end{array}$} & \multirow{2}{*}{$\begin{array}{l}\text { Average } \\
\text { Consumption Per } \\
\text { Month } \\
12506\end{array}$} \\
\hline Age & $\geq 29$ & 15 & & \\
\hline & $30-39$ & 20 & 26494 & 17491 \\
\hline & $40-49$ & 20 & 28416 & 18818 \\
\hline & $50-59$ & 30 & 30820 & 21715 \\
\hline & $\leq 60$ & 15 & 20999 & 10567 \\
\hline Total & & 100 & 27155 & 17750 \\
\hline
\end{tabular}




\section{Analytical Framework}

A total number of 110 samples size was used from the entire population (No. of women obtained micro finance) as sample size to proceed our research. The study universe was the districts of Afghanistan where population of working women is higher. Proportionate allocation technique followed for sample selection from selected six districts: Jalalabad, Laghman, Kunar, Kama, Khogyani, and Kot of Afghanistan. Proportionate allocation technique use to allocate friction of samples in each strata (Jalalabad, Laghman, Kunar, Kama, Khogyani, and Kot) which is proportion of total population. There are total 421 districts in Afghanistan and each district comprised on more than 1000 villages. This research has assigned value to districts from 1-6. Total population of working women (obtained loans through micro financing) in selected districts was about 4005. District wise it was 1055, 928,730, 510, 400, 328 in Jalalabad, Laghman, Kunar, Kama, Khogyani, and Kot respectively. Through proportionate allocation technique, sample from each district such as 29, 27, 20, 14, and 11 and 9 respectively are selected.

Table 3: Selection of Sample Respondents

\begin{tabular}{lcc}
\hline Study Universe & Women Obtaining MFL & No. of Respondents \\
\hline Jalalabad & 1055 & $1055(110 / 4005)=29$ \\
Laghman & 982 & $982(110 / 4005)=27$ \\
Kunar & 730 & $730(110 / 4005)=20$ \\
Kama & 510 & $510(110 / 4005)=14$ \\
Khogyani & 400 & $400(110 / 4005)=11$ \\
Kot & 328 & $328(110 / 4005)=9$ \\
\hline Total & 4005 & 90 \\
\hline
\end{tabular}

Note: MFL reports micro finance loan

This research has used descriptive statistics method. The given data was analyzed using Statistical Package for Social Sciences (SPSS) in order to check the reliability of the data by using cronbach's alpha test. To measure the degree of relationship and dependency of explained variable over explanatory variables, regression estimates were employed. The cross sectional data was estimated by single equation multiple regression model. Women empowerment is measured with decision making, participation rate on social and cultural activities, role in household decision making.

\section{Econometric Model}

Women empowerment is a multi-dimensional phenomenon but this research analyzed social development and poverty alleviation through micro financing. Linear regression equation described the relationship between dependent and independent variables. Analysis is done to investigate the impact of micro finance on social development and poverty alleviation by women empowerment. Therefore, this research has divided the determinants in 3 groups: Social variables, Economic variables and Demographic variables. Social variables were (level of living standard, education level, marginal propensity to consume (purchasing power), Economic factors were (consumption per month, income level, saving level, earnings/profit margin) Demographic factors were (age of the respondent, family size, marital status).

However, measuring the impact of microfinance on selected variables, income is used as proxy for living standard (social development), women empowerment, and poverty alleviation. Here MPC is the proxy for living standard and women empowerment and $\mathrm{Yi}$ is the 
proxy for poverty alleviation and social development. Dummy variable used for qualitative variables by assigning the value: 1 for improved living standard and otherwise, in case of education 1 for educated and 0 otherwise, in case of marital status 1 was assigned to married and 0 otherwise. Women empowerment score measured by the responses gathered through questionnaire. Respondents rate the dimension from 1-7, such as role of women participation in making house hold decisions, social and cultural activities. Natural log is used for women empowerment score. The estimation of selected variables by regressing them against micro finance loans followed by (Niaz \& Iqbal, 2019) as Yi (change in income) representing relationship among income, women empowerment score, social development, marginal propensity to consume, poverty alleviation and living standard because change in income/consumption is not measurable or can cause measurement because mostly respondents feel reluctant while giving correct income estimates. Therefore, it is used as proxy variable and the effect is received from collective response of influenced variables. The variables were collectively regressed against Micro finance loans.

$Y i=\delta o+\delta 1 M P C+\delta 2 W E S+\delta 3 S D+\delta 4 P E+\delta 5 L S+\varepsilon i$

$Y i=\alpha o+\alpha 1 M F L i++\varepsilon i$

$Y n i=\beta o+\beta 1$ age $+\beta 2 f$. size $+\beta 3 E d u$.level $+\beta 4$ income $+\varepsilon i$.

In the above equation, Yni indicates purchasing power / level of consumption raised by the increased levels of income due to women empowerment through micro financing.

$M P C=\Delta C / \Delta y$, change in consumption due to change in income

$\mathrm{Y}=$ level of Income per month

$\mathrm{MFL}=$ Micro finance loans

$\mathrm{MPC}=$ marginal propensity to consume

$\mathrm{PE}=$ Poverty Elevation

$S D=$ Social development

LS = Living Standard

WEs $=$ Women empowerment score

$\delta 1, \alpha 1, \beta 1=$ slope parameters

$\delta 0, \alpha 0, \beta 0=$ intercept

$\varepsilon i=$ Expected Error

$i=$ No. of respondents

\section{Results and Discussions}

\section{Findings}

The given Table 4 indicates the reliability of data and checked with cronbach alpha test. The outcomes found satisfactory for all of the determinants ranged from 0.766 to 0.986 .

Table: 4 Cronbach's Alpha Test of Reliability

\begin{tabular}{ll}
\hline Indicators & Cronbach's Alpha \\
\hline Women empowerment score & 0.812 \\
Micro financing & 0.986 \\
Social development & 0.766 \\
Income levels & 0.815 \\
Poverty Alleviation & 0.822 \\
Marginal propensity to consume & 0.787 \\
\hline
\end{tabular}




\section{Regression Estimates}

The below Table 5 indicates the estimates given by regressing income level as proxy of other determinants against micro finance loans. The coefficient of intercept was ignored as intercept shows the impact of all other variables (which left outside the model) when the effect of independent variable is zero however, in this research all the selected determinants could not be zero at any case. All the independent variables were found significant at both $1 \%$ and $5 \%$ level and according to $t$ values, there exist positive relationship between micro finance, women empowerment, social development, and all the determinants except poverty alleviation. There is significant impact of micro financing on poverty alleviation and women empowerment. Exposure of MFL, impact social development positively by changing the levels of income overtime. The coefficient of social development showing that as the gauge of micro financing expends by $1 \%$ it brings social development in the society up to $16 \%$. The coefficient of women empowerment score indicates greater exposure of micro financing that impact positively women empowerment. As the exposure the micro financing by 1 percentage points it increase the chance of women empowerment by 12 percentage points. Increase the rate of empowering women will improve social development significantly and alleviates poverty by $14 \%$. As the levels of income used as the proxy of other variables therefore, it has also positive impact. The increase in income levels give rise to increase in purchasing power by $15 \%$ points. Work experience is social indicators showing positive relationship with income levels. Education is also an important social indicator showing that as level of education increases the income could increase by 18 percentage points. With increased in income levels by empowering women through micro financing, the purchasing power also rises up to $15 \%$ points, if any rises by $1 \%$.

The proportion of the variation in dependent variable $Y$ explained by independent variables, jointly the quantity that gives this information is known as multiple coefficient of determination or $\mathrm{R}^{2}$ (Gujrati, 2009). The $\mathrm{R}^{2}$ (coefficient of determination) is the proportion of variation explained in dependent variable by independent variables which was 0.75 , showing that collectively independent variables explains around $75 \%$ of the variation in dependent variable.

The value of F-Statistics 55.20 indicates the model significance at $5 \%$ significance level accepted the hypothesis regarding collective effect of independent variables.

T-statistics indicating that all the independent variables are significant predictors of dependent variables. Here the $t$ value found greater than 1.8 showing all the variables significantly predict MFL.

Table: $5 \quad$ Regression Estimates

\begin{tabular}{lllll}
\hline Micro Finance & Beta & St. Error & T & Sig. level \\
\hline Women empowerment & 12.66 & 3.5 & 5.2 & 0.005 \\
score & & & & \\
Social development & 0.165 & 0.01 & 11.02 & 0.000 \\
Income levels & 0.158 & 0.04 & 29.11 & 0.000 \\
Poverty alleviation & -0.144 & 0.006 & -16.8 & 0.001 \\
Purchasing power & 0.150 & 0.03 & 13.6 & 0.000 \\
Working years & 9.730 & 56.137 & 0.173 & 0.030 \\
Education level & 18.717 & 46.257 & 1.951 & 0.054 \\
Income & 0.483 & 0.040 & 12.036 & 0.000 \\
\hline
\end{tabular}




\section{Discussion}

Financial institutions since the very beginning, contribute significantly for the betterment of mankind. As compare to developed economies, under developed or less developed benefited more from establishment of financial institutions. Financial institutions have been offering several schemes and instruments to support the people and businesses. Micro financing is one of the important tool of financing which is designed to support the vulnerable residents of developing and less developed nations. Micro credit aimed at the betterment of those individuals/businesses that struggled and urge to lead a prosperous life and developed business. Micro financing has been also found beneficial in case of women empowerment and social development in many countries like Afghanistan. This research as was conducted in Jalalabad, Laghman, Kunar, Kama, Khogyani, and Kot Afghanistan with the objective to investigate the impact of micro financing in women empowerment, social development and poverty alleviation in Afghanistan. In this research in-depth insight was given to the said problem through existing literature and collected data from the selected districts of Afghanistan.

The estimated results by regressing income levels (used as proxy for social development, purchasing power, poverty elevation, women empowerment and earnings) against micro finance loans. This research has used proxy for those variables where the chance of measurement error was high because most of the respondents feel reluctance in disclosing accurate estimates of earnings and expenditures. The outcomes of this research supported the hypotheses: $\mathbf{H}_{\mathbf{1}}$ : Microfinance positively and significantly affects women empowerment and $\mathbf{H}_{2}$ : Microfinance positively and significantly affects social development. Micro financing was in positive relationship with women empowerment and social development, however negative with poverty alleviation. The outcomes of this research is in line with earlier researchers that have provided evidence that micro finance has positive association with women empowerment and social development (Herani, Dhakan, 2017; Kim et. al., 2017; Mawa, 2018; Mohindra, Katherine, Haddad, 2015; Mohammad, Khan, Mohammed, Rahaman, 2017; Darwish \& Abdeldayem, 2019). As the awareness towards women empowerment increases, it gives rights to the women in order to perform their duties in good manners such as increased participation rate in social and cultural activities, freedom of decision making, confidence to deal with the situations accordingly, and freedom of mobility and a way to flexible life. Other socio-economic and demographic determinants were also found significant, documenting positive relationship with purchasing power that increases with rise in income levels.

Micro financing helps several women in commencing or expanding their businesses. Women empowerment is correlated with social development as the social status and living standards of families rises by the capability of fulfilling basic needs, to boost up purchasing power which in turn a way towards alleviating poverty. The outcomes indicated that micro finance is a significant tool of financial institutions that instill women and builds their power of decision making both in domestic activities and in business \& social activities. Furthermore, it boosts the confidence level of women by making economic contributions in support of families which is considered as a step towards prosperity. Sum up the discussion, microfinance plays a significant role to empower women and develop socially by making them independent and enable them to earn sound income and support themselves and their families. 


\section{Conlcusion}

Micro financing is used an important tool for the growth and development of an individual and business. Easy way of financing and lowering interest rates enhance the productivity of financial institutions. Establishment of new banks is also a step towards prosperity and social development in a developing country like Afghanistan. The outcomes of this research supported the research hypotheses that microfinance positively and significantly affects women empowerment and social development. Micro financing was in positive relationship with women empowerment and social development, however negative with poverty alleviation. As the awareness towards women empowerment increases, it gives rights to the women in order to perform their duties in good manners such as increased participation rate in social and cultural activities, freedom of decision making, confidence to deal with the situations accordingly, and freedom of mobility and a way to flexible life. Other socio-economic and demographic determinants were also found significant, documenting positive relationship with purchasing power that increases with rise in income levels. Sum up the discussion, microfinance plays a significant role to empower women by making them independent and enable them to earn sound income and support themselves and their families.

\section{Recomendations}

It is highly recommended that the financial institutions working in underdeveloped economies like Afghanistan should design such an instrument specifically for women with easy availability and lower mark ups to encourage women participation in every aspect of life/society and business in urban areas and particularly in rural areas. Nations can only succeed by equality of men and women, by remove discrimination and by supporting and empowering women to encourage them.

\section{Acknowledgments}

I would like to express my sincere gratitude and appreciation to Higher Education Development Program (HEDP)/ World Bank and Ministry of Higher Education (MoHE), Afghanistan for the help they gave me and whose financial contribution facilitated the successful completion and publication of this research.

\section{References}

Ali, A., \& Alam, M. A. (2017). Role and Performance of Micro-credit in Pakistan. International Journal of Business, 3(15), 137-151.

Afghanistan Central Statistics Organization (2019). https://nsia.gov.af/en

Afghanistan Research Newsletter 25 (2019). documents.worldbank.org

Avolio, B. J., Yammanno, F. J., \& Bass, B. M. (2016). Identifying Common Methods Variance With Data Collected From A Single Source: An Unresolved Sticky Issue. Journal of Management.

Bakhtiari, S. (2016). Micro-finance and Poverty Reduction (Some International Evidence). International Business and Economics Research Journal.

Chapman, L. J., \& Chapman, J. P. (2017). Illusory correlations as an obstacle to use of valid chodiagnostic signs. Journal of Abnormal Psychology.

Darwish, S., \& Abdeldayem, M. M. (2019). Risk Management and Business Ethics: Relations and Impacts in the GCC. International Journal of Civil Engineering and Technology, 10(10), 489-504. 
Emily, W. (2019). The State of Transitional Justice in Afghanistan: Actors, Approaches and Challenges

Gopalan, S. S. (2017). Micro-finance and its Contributions to Health Care Access (A Study of Self-Help Groups (SHGS) in Kerala), Health and Population Department of Kerala on Health and Population.

Gurses, D. (2018). Micro-finance and Poverty Reduction in Turkey, Perspectives on Global Development and Technology, pp 90-110.

Gangadhar and Malyadri. (2015). Impact of Microfinance on Women Empowerment: An Empirical Evidence from Andhra Pradesh,vol 4(2),pp 1-8.

Haughton, J. H., \& Khandker, S. R. (2018). Hbook on Poverty and Inequality. Washington,DC: World Bank.

Hicks, R. (2019).The Capability Approach: Insights for a new Poverty Focus." Journal of Social Policy, 41, 291-308.

Mawa, B. (2018). Impact of Micro-finance Towards Achieving Poverty Alleviation. Pakistan Journal of Social Sciences, 5 (9), 876-882.

Mansfield, D. (2018). Where Have all the Flowers Gone? Assessing the Sustainability of Current Reductions in Opium Production in Afghanistan.

Mohammad, A. K., and Mohammed, A. R. (2017). Impact of Microfinance on Living standards, Empowerment and Poverty Alleviation of Poor People: A Case Study on Microfinance in the Chittagong District of Bangladesh, M.Phil. Thesis; Umeå School of Business.

Mohindra, K. S., \& Haddad, S. (2015). Women's Interlaced Freedoms: A Framework Linking Micro credit Participation and Health. Journal of Human Development, vol 6( 3).

Morris, G., \& Barnes, C. (2016). An assessment of the impact of microfinance: A case study from Uganda. Journal of Microfinance,vol 7(1), 40-54.

Niaz and Iqbal. (2019). Effect of Microfinance on Women Empowerment: A Case Study of Pakistan, Vol. 13, No. 1 Page 53-60.

Weiss, J., Montgomery, H., and Kurmanalieva, E. (2013). Micro Finance and Poverty Reduction in Asia: What is the Evidence? ADB Institute Research Paper Series.

Zaman, H. (2015). Assessing the Poverty and Vulnerability Impact of Micro-Credit in Bangladesh: A case study of BRAC. World Bank. 